\title{
Perverse Effects of the Didactic Contract on the Disengagement towards Sport and Physical Education among Students of Humanities in Kinshasa: Case of Few Catholic Aided Schools
}

\author{
Ewamela, $A^{1}$., Mandoumou, $P^{1}$., Kena Lubika, $A^{2}$., Lembe, $G^{1}$., Entsiro, $F^{1}$., \\ Moboza Ndongo, E. ${ }^{3}$, Bongbele, J., ${ }^{1,2}$ \\ ${ }^{1}$ Laboratory of Didactics Physical Activities and Sports, Higher Institute of Physical Education of the University MarienNgouabi , Congo -
Brazzaville. \\ ${ }^{2}$ Department of Physical Education and Sports Management, Faculty of Sciences, National Pedagogical University, Kinshasa, Democratic \\ Republic of Congo \\ ${ }^{3}$ Teaching Staff of the Information Technologies and Communication and Sports Management, Higher Institute of Physical Education of the \\ University Marien Ngouabi, Congo -Brazzaville
}

\begin{abstract}
This article focuses on the examination of the perverse effects of didactic and their impacts in the disengagement of sport and physical Education of pupils Kinshasa's high school. In the effect, 217 (195 with 45 minutes a week on sport and physical Education (experimental group) and 22 with 6 hours a week of practical APSA (control group) under the guidance of their teachers during 13 weeck, attended in this study. This study consisted in indirect observation of video, in order to identify and determine numerical event of the pervers effects of didactique (Topaze, Sisyphe, metacognitive glissement, incomprehension attentive) and a documentary analysis to save the number of absents in relation with the disengagement in sport and physical Education. The mean was compared with the Student test. But, the correlations between the effects and the disengagement in sport and physical Education were determined by the test of Pearson and compared by the Student in using neperien logarithm.
\end{abstract}

Keywords: Perverse effects of didactic, disengagement in sport and physical Education.

\section{Introduction}

The effectiveness of learning depends on the pedagogical relationship between the agent and the subject. This relationship is determined by the mutual commitment and shared responsibility between the two partners of pedagogical action and results in terms of didactic contract (Brouseau, 1986; Henry, 1991).The didactic contract is a system of reciprocal obligations, largely implicit, that determines what each partner (teacher and taught) has the responsibility to manage and which will be one way or another, responsible to the other. It depends first of the adopted teaching strategy.

The didactic contract is respecting the principle of negotiation which is an agreement between the subject and the agent upon relative exchange to the objective and learning tasks presented by the agent. This helps to clarify the purpose and initiate learning by encouraging the motivation in students (Famose, 2000).It is suitable in teaching through the proposal be simple tasks to solve a problem when learning or new learning situations from the success in the subject.Indeed, the pedagogical choices, style of work required of students, learning objectives, the epistemology of teachers, conditions of evaluation are among the key determinants of educational contract to be adapted to these context that meant Baruk quoted by Brousseau (1998) and Sensevy (2006).
However, many of the difficulties of students is explained by the effects of contract, improperly installed or misunderstood. Moreover, the subject may divert the instructions and have the feeling of being bullied .De Meanwhile, the teacher may during the intervention drag an approach to another which he has no control, verbalize the student as to allow him to say what he did not do (Brousseau, 1986).Moreover, not taken into account the environmental conditions and the restriction of the learning period (Ewamela, 2005) can prevent the achievement of predefined objectives, induce breakage of didactic contract. Thus, we proposed to examine the influence of perverse effects of didactic in Physical Education and Sports on the disengagement of students of Humanities of Kinshasa. This is a major concern which leads us to wonder about the existence of the adverse effects of the teaching during Physical Education and Sports lessons and their impact on the disengagement in Physical Education and Sports among students of Humanities of Kinshasa. To this end, the following assumptions were made:

- The lessons of Sports and Physical Education are an opportunity event to show the pervers effects of didactic in classes of Humanities Kinshasa;

- The perverse effects of didactic are an important factor in Physical Education and Sports disengagement among students of Humanities Kinshasa 


\section{International Journal of Science and Research (IJSR) \\ ISSN (Online): 2319-7064 \\ Index Copernicus Value (2013): 6.14 | Impact Factor (2015): 6.391}

In conducting this study, the objectives are as follows:

- Decrypt the images and raise the event frequency of preserve effects of didactic in Physical Education and Sports.

- Evaluate the influence of perverse effects of didactic on the disengagement in Physical Education and Sports of students of humanities Kinshasa.

The interest of this study is to evaluate optimally the frequency and influence of perverse effects of didactic on the disengagement in EPS in order to contribute to improving the efficiency of learning.

\section{Materials and Method}

The study focused on 195 students of literary sections (Latin-Philosophy), Science (Mathematics, Physics, Biochemistry) and pedagogic of Humanities Catholic aided schools (College Cardinal Etsou, Bakanja Institute, College Abbe Loya, College Saint Robert).submitted a weekly lesson of 45 minutes constituting the experimental group and 22 students of the Physical Education Section of the College Saint Pierre submitted to 6 hours of weekly practice Sports and Physical Activities and Art gathered in the control group.

This study was conducted in two parts, namely:

Indirect observation was consisting filming the lessons of Education Physical and Sports. The images were deciphered to determine the frequency of manifestation of the perverse effects of the didactic in EPS have made the following study variables:

- The topaz effect that is manifested by the non student improvement despite the assistance provided by the teacher to solve a problem situation during the implementation of a learning task. This leads to the nonachievement of the objective defined and negotiated beforehand;

- The Sisyphus effect perceptible through the disengagement of the student following the continuous demand of the agent when it fails every repetition

- The sliding metacognitive effect which is characterized by the change of the task by the teacher in order to circumvent the problem without solving it;

- The effect of waiting misunderstood: that was manifested by the award of the learning fails to students by the teacher.

- Recording student absences of humanities Kinshasa during lessons EPS by analyzing call records.

Data from the indirect observation and absences were treated according to descriptive statistics with Microsoft Excel. Statistical tests used were those of Student and Pearson (Robert \& James, 1969).

\section{Results and Discussions}

In order to check the perverse effects of didactic on the disengagement in EPS students of Humanities of some subsidized schools Catholics Kinshasa, it was necessary for us to present and interpret the first perverse effects of teaching and the correlations between the adverse effects of the didactic and disengagement in EPS of these students.

Average and standard deviation ( $\mathrm{x} \pm \delta \overline{)}$ adverse effects of didactics (topaz, Sisyphus of metacognitive shift, waiting misunderstood) and disengagement of students in the experimental and control groups were presented in Table 1.

Table 1: Average and standard deviations $(\mathrm{x} \pm \delta \overline{)}$ of the effects of didactic and disengagement in EPS students of experimental and control groups:

\begin{tabular}{lcccc}
\hline & Experimental Group & Control Group & \multicolumn{2}{c}{ Significance } \\
\cline { 2 - 5 } & $(\mathrm{n}=195)$ & $(\mathrm{n}=22)$ & $\mathrm{T}$ & $\mathrm{P}$ \\
\hline Topaz effect & $63,11 \pm 1,45$ & - & - & - \\
Sisyphus effect & $62,99 \pm 1,31^{* * *}$ & $47,14 \pm 0,83$ & 79,28 & $<0,001$ \\
Sliding metacognitive effect & $42,14 \pm 2,81^{* * *}$ & $29,18 \pm 0,91$ & 17,88 & $<0,001$ \\
Effect of waiting misunderstood: & $11,29 \pm 1,76^{* * *}$ & $3,18 \pm 0,91$ & 34,63 & $<0,001$ \\
Disengagement & $8,24 \pm 2,49^{* * *}$ & $1,18 \pm 0,91$ & 26,79 & $<0,001$ \\
\hline
\end{tabular}

*** : highly significant difference $(\mathrm{P}<0,001)$

The results obtained showed that the topaz effect was not demonstrated in the experimental group $(63.11 \pm 1.45)$. These results are explained by the failure of students despite the help of the teacher marked by explanations, guidelines, criteria of success, achievement and support, corrections and remedial situations presented by the teacher. To this end, Brousseau (1986) said that the topaz effect is manifested by then on improving of the subject whatever the assistance provided by the agent to solve a problem situation in learning. In this study, the topaz effect occurred in the experimental group by several facts:
- Despite the demonstration and correcting the teacher while learning the ventral roll after finding the realization unsuccessfully to dodge and use of the hand to receive in the pit and his insistence in asking the full extent of the leg in order not to touch the bar when crossing, the students do not respect this and fail to perform this task.

- At asks students to take the momentum of a race that determines the beat with both feet, placing manuals support on the back of his partner, the crossing with legs apart and completely, look at the landscape. Despite the learning situations proposed as palliative means, students especially girls are dispersed manner, hesitate when beaten and others have legs bent. In view of the above, the 


\section{International Journal of Science and Research (IJSR) \\ ISSN (Online): 2319-7064 \\ Index Copernicus Value (2013): 6.14 | Impact Factor (2015): 6.391}

previously defined objectives are not achieved due to the manifestation of topaz effect during EPS lessons which have been subject students in the experimental group. During learning legs apart jump with human craft in Gymnastics, teacher.

The predominant manifestation of topaz effect in the classrooms of the experimental group is also linked to the notion of "problem" and the "problem-solving situations" that are at the center of reflection on the efficiency of learning. Indeed, the "problem" is defined as the gap between the required capabilities and the actual capacity of the shift students. This represents the adaptive potential that the student can implement to address the problem. The engine problem that is facing the student lies in the fact that he has no immediate answers in his motor repertoire (Famose, 1991) .The answers must be developed over time and require obstacle clearance from where students not only mobilizes the driving resources but also cognitive and emotional resources (Touboul, 2011). The mobilization of this potential that matches the resources of the student does not always happen without breaking the didactic contract.

The results we have achieved also reveal that the manifestation of the Sisyphus effect was significantly greater in the experimental group classes than in the control group $(62.99 \pm 1.31$ vs $47.14 \pm 0.83 ; \mathrm{P}<0.001)$. The most important manifestation of the Sisyphus effect in the experimental group of classes is dependent on continued demand from the teacher without user control means following the failure of students during motor learning. In this situation of perversion, he missed that teacher to identify the causes of the error to give the criteria for success and indicate the destination of the ball. But when students performing the tasks proposed to them without that are specified by the teacher's success criteria, so they perform according to their Understanding .By result, they fail and eventually give up learning. Bessy and Cazenave (1992) observed the following fact: "the teacher noting that there is a difference between the proposed task and that carried, told the student that you have not succeeded. He repeated it several times without specifying what he must actually accomplish the task. «For the teacher, it perceives a malfunction in the course of the task as it was designed, without precisely identifying the origin.

The dysfunction in the classes of the experimental group is also dependent learning errors that must be corrected. Since errors are characteristic behaviors to correct, in terms of a logic of sports physical activity previously defined (and Thepaut Leziart, 2013). In addition, learning errors are related to the subject that learns. Indeed, in EPS, the error is not synonymous with success in motor task, that is, of non compliance with its criteria for success. Moreover, the error can be detrimental to the student, altering both its progress and sense of competence.

Failure Error identification process creates an incompatibility of operation that the teacher handles ". Hence arises the concept of performance whose relationship with learning is so often thought of as a strong link between a learning situation and its supposed effects on student performance benefits. In fact, analyzing the performance disciplinary relationships and learning from stance LahanierReuter (2008), is to interpret the sequences of actions such as movement within the "didactic system". It can generate the reproduction of inappropriate behavior.

The reproduction of appropriate conduct must be considered as an expression of the failure because no perspective of evolution is possible. This is why it comes to ease results of the knowledge of its action (Schmidt, 1999) through all procedures that encourage students to succeed in its delivery and help to compare what he did with what to do (feedback, success criteria). For without the perception of error, means to overcome it, the mistake can lead to failure and let the student in a discouraging and demeaning status of eternal beginner. The effort asked students may seem to them as excessive. The teacher then wanted her students succeed. He tends to facilitate their work in different ways including through too abundant explanations that sometimes have the opposite effect and can actually help understand (Touboul, 2011). Regarding the sliding metacognitive effect, it is significantly observable in classes in the experimental group compared to the control group (42.14 \pm 2.81 vs. $29.18 \pm$ $0.91 ; \mathrm{P}<0.001)$. The important event of the sliding metacognitive effect among experimental subjects can be explained by the use of a new method or the proposed new task rather than solve the problem faced by students during learning technical or tactical element that is complex. This reflects an obstacle epistemological identified that we can understand the lack of definition of the intervention program by the teacher does not have didactil landmark. So under pressure from students and teach what students choose to do (and therefore do not learn) and manages the class group to the detriment of learning because of the peer pressure that prevents individual learning or that of the hardware class organization with an environmental design that limits learning. In this regard, Thepaut and Leziart(2013)observed the following fact in rhythmic gymnastics (final production), "the show can give meaning to learning, but is a real pressure for students and teachers. The lack of regulation by using a main element is the panel of adaptive responses of students during the learning unit (and the lesson cycle) is the origin of this teacher's evasive attitude. The manifestation of this effect reflects the proposed content that does not seem essential, if unsuccessful, teachers passing other content. In this study, the metacognitive slip effect was observed during a basketball lesson by the proposed learning dribble while that of the pass previously started has not been successful. We could explain this shift by the issue of forward progression identified by the teacher but he yields another. This abandonment of the task is applied only when the teacher questions the relevance of the content taught account from that group by going on one hand and the individual using the dribble with over the other risks. He then abandoned a task performed with failure to offer a practical situation and maintaining the educational relationship abandoning the knowledge. En Indeed, when teaching activity failed, the teacher takes his own explanations and heuristics as objects of study instead of the true scientific knowledge (Bouseta, 2010).

Similar results to those of the two previous effects were also obtained in the event of pending misunderstood effect with greater value in classes in the experimental group than the 


\section{International Journal of Science and Research (IJSR) \\ ISSN (Online): 2319-7064 \\ Index Copernicus Value (2013): 6.14 | Impact Factor (2015): 6.391}

control group $(11.29 \pm 1.76$ Vs. $3.18 \pm 0.91 ; \mathrm{P}<0.001)$ (Table I). It depends on the students' responsibility in the failure to learning. This responsibility for the failure incumbent on the student reflects the belief that a response expected of students is obvious. The responsibility for the failure incumbent on the student assumes that problem solving situations do not always have the function of organizing the devolution but rather a place close to the activity programmed device containing nested task complexity growing.

The disengagement in Physical Education and Sports was significantly higher in classes in the experimental group compared to the control group (8.24 \pm 2.49 vs. $1.18 \pm 0.91$; $\mathrm{P}<0.001$ ) (Table 1). The higher disengagement in EPS of pupils in the experimental group was due to the inadequacy of the didactic contract and its rupture. Indeed, inadequate teaching contract causes loss of commitment and lack of motivation. ROAD (2011), in this context, meant that the practice stressful sports fans do not accompany the whole life depending on the commitment wanes and motivation that dried up. The stress generated by the practice of sports and artistic physical activity is a psychological and physiological disturbance factor of the body (Billat 2000; Ewamela, 2005).

The disengagement in EPS is linked to biographical factors (morphological and accidental), school cultural identity. Biographical factors of morphological type associated with obesity determine the breaks in Physical Education and Sports (Thibault \& al., 2010). The school cultural identity in the humanities is closely related to the beginning of the specialization of training with the above sections. These sections induce a favorable selection in the mobilization of cognitive and conative resources at the expense of driving behavior that characterizes the learning engine. Here we taking a social position based on school counseling student in engaging advantage in learning the optional subjects on the one hand and any interest granted to the other Physical Education and Sports.

However, the content of what is learned is not negligible. Delignieres (2006) estimated that if the direction comes from the process, it also feeds the cultural resonance of skills. This is why the cultural representation of the teaching of media practices seems essential. It should be noted that we should not confine the student to what he knows a priori. This learning primate raises new questions for the teacher. The knowledge and know-how are available in a special way by the institutions (LATCH et al., 2002). This is consistent with the work of the research team Education, Socialization, and university Locales- Community (Escool of Paris VIII) which showed that it is the student who built his own academic position during its singular history, alleged instead that is to say the equivalent to the social status of the mirror can be claimed, accepted or refused (Mourgues, 2000). In fact the individual does not question the world, but he appropriates in her about logic.

Table 2 shows the correlations between the abovepervers abovementioned effects and disengagement in Physical Education and Sports among students in the experimental and control group groups.

Table 2: Correlations between the perverse effects of the didactic and disengagement of students in experimental and control groups

\begin{tabular}{|c|c|c|c|c|}
\hline & \multirow{2}{*}{$\begin{array}{c}\text { Experimental } \\
(n=195)\end{array}$} & \multirow{2}{*}{$\begin{array}{c}\text { Control } \\
(n=22)\end{array}$} & \multicolumn{2}{|c|}{ Significant } \\
\hline & & & & \\
\hline & $\mathrm{r}$ & $\mathrm{r}$ & $\mathrm{t}$ & $\mathrm{p}$ \\
\hline Topaz-disengagement effect & 0,85 & - & - & - \\
\hline Sisyphe-disengagement effect & 0,243 & 0,085 & 1,39 & NS \\
\hline Sliding metacognitive-disengagement effect & $+0,98 * * *$ & 0,95 & 3,91 & $<0,001$ \\
\hline Effect of waiting misunderstood-disengagement & $+0,99 * *$ & 0,98 & 2,92 & $<0,01$ \\
\hline
\end{tabular}

NS : No Significant Difference

*** Highly Significant Difference

** Significant Difference

It appears from the analysis of the results shown in Table 2 that the correlations between the negative effects of the didactic Physical Education, Sports, and disengagement of students experimental and control groups were all positive. These results show a strong correlation between topaz effect and disengagement in Physical Education and Sports among students in the experimental group (0.85). This reflects the influence of topaz effect on the disengagement Physical Education and Sports related psycho physiological factors: inattention students which affects the perception of the action, the processing of information in memory, selection and manufacture of motor response, bad adjustments and organizations motor commands that could be attributed to poor muscle activation intensity and timing of activations, the imperfect mechanisms of planning and programming of the movement who come by decision making involving the processing serial route information for the development of an initial engine program that will be sent to the muscles by the motor neuron, the weak mobilization of energy resources in the activity of the body Apsa and development in cognitive-motor potential that can affect motor act to the point of inducing errors including the difficulty of stopping them while learning is a source of rupture. In view of the above, the psychophysiological factors are responsible for the repeated failure among students despite the large teacher intervention and thus disengagement in Physical Education and Sports.

By cons, these results indicate that the disengagement is highly correlated with the Sisyphus effect and correlations are not significantly different between students of the two groups (experimental and control). This is due to the non 


\section{International Journal of Science and Research (IJSR) \\ ISSN (Online): 2319-7064 \\ Index Copernicus Value (2013): 6.14 | Impact Factor (2015): 6.391}

remediation repeated failures. The monotony of learning is responsible for the disengagement Physical Education and Sports insofar as the perpetuated habits can be a source of nuisance in Physical Education and Sports.

Disengagement is closely related to the metacognitive slip effect, even more important in the experimental group compared to the control group (0.98 vs. 0.95; $\mathrm{P}<0.001)$. This reflects a drop of students in EPS due to the presentation of a new learning object or a new method by the teacher from the perception by him for the failure of his students. This metacognitive shift reflects the lack of skills of teachers witness to the lack of ongoing training to develop professional skills includes: ability to activate during action, knowledge built in and through action. For the design of the action as strongly inserted in a context is proposed in the model of "situated action" (Suchman, 1987). The skill lies not in the resources (attitudes, knowledge, skills) to mobilize but in the same mobilization of resources. Because competence is about the "ability to activate" (The Boterf,1997;Altet, 1994).

The correlation between the disengagement in EPS and the effect of misunderstood wait is significantly higher among students in the experimental group compared to the control group ( 0.99 vs. $0.98 ; \mathrm{P}<0.01)$ (Table 2$)$. The important link between the disengagement in EPS and the effect of waiting misunderstood especially among students in the experimental group was due to the concern of teachers in the management of disciplinary issues rather than support for students in construction their learning. This feeling of abandonment of discipline for the sake of discipline disrupts this implies that most strongly, relationship. The priorities then become the classroom atmosphere, conflict management and regaining the public. Indeed, in the classrooms of the experimental group with a large numbers (39, 41, 43, 62), observation revealed disciplinary issues which led teachers to invest in the restoration of order and time of return on the content of education especially with insufficient equipment in an inappropriate area has led to failures in learning. Furthermore, non-compliance indicators of the evaluation of the pupils' (instructions and success criteria) are responsible for these failures to learning. Responsibility for these failures lies in learning to students. In isolation, alone with his students, the teacher does not consider itself as having the right for error. There is no question here of an error undermining the physical integrity of students, but simply the most general impression of the group that what is proposed "not working", that the instructions are not followed and that 'in summary the teacher does not get these students what he had planned (prescribed work / real work).Jointly, it does not, either, that his students can accept from him any form of hesitation, uncertainty would be ipso facto attributed to incompetence. Ultimately, the perverse effects of the didactic contract are much obvious and responsible disengagement in Physical Education and Sports.

\section{Conclusion}

The Physical Education and Sports lesson requires pedagogical relations maintained by the action of educational partners, namely the teacher acts and the students react to orders (shares their teacher). In this mutual commitment and shared responsibility reflecting the didactic contract, the negative actions of each partner on the pedagogical action can pervert all of them and prevent the achievement of learning objectives: where the breach of contract in relation with the greatest manifestation of the perverse effects of the teaching in the experimental group students (sections: literary, scientific and educational) compared to their counterparts in the control group (Education section of Sports and Physical). The latter is responsible dropout in general and disengagement in Physical Education and Sports in particular. After this study devoted exclusively on the educational factors of disengagement of students in Physical Education and Sports, special attention should be directed towards psychological, sociological and ecological factors disengagement of students in Physical Education and Sports.

\section{References}

[1] Altet, M. (1994).Comment interagissent enseignant et élèves en classe ? Revue Française de Pédagogie.

[2] Baruk, S. (1998). L'âge du capitaine. In Brousseau , G. Théorie des situations, La Pensée Sauvage.

[3] Bessyo\&Cazenave, S-H. (1992). Le développement des ressources aérobie en EPS : Illusion ou réalité. In Bessy, O. (2000). Les loisirs corporels et diversité des pratiques : enjeux économiques et sociaux, "http://perso.wanadoo.fr/jean-paul. Castex/Bessy. Html, consulté le 14/10/2013".

[4] Billat, V. (2000). Physiologie et méthodologie d'entraînement : De la théorie à la pratique du sport, Bruxelles : De Boeck Université, 396 pp.

[5] Bouseta, A. (2010). La didactique : le contrat didactique. Ministère de l'Education Nationale, de l'Enseignement Supérieur, de la Formation des cadres et de la Recherche scientifique du Royaume du Maroc.

[6] Brouseau, G. (1986). Fondements et méthodes de la didactique des Mathématiques, Recherche en didactique des Mathématiques. In Brouseau, G. (1990). Le contrat didactique : le milieu, in RDM. La Pensée Sauvage, GRENOBLE, vol.9, n³ : pp 309-336.

[7] Delignieres, D. (2006). Le sens des apprentissages en EPS : Education motrice ou éducation sportive ? In Dufour, Y. Gérer motivation et apprentissage en EPS, Lille : Editions AEEPS régionale de Lille, pp 67-72.

[8] Ewamela, A.(2005). Enseignement de l'EPS en ambiance chaude et humide : Perturbations physiologiques et modèles de remédiation. Thèse unique de Didactique des APS, Chaire UNESCO-ENS en Sciences de l'Education pour l'Afrique Centrale, Université Marien Ngouabi, Brazzaville (République du Congo), n4, 2005.

[9] Famose, J. P. (2000). Apprentissage moteur et motivation. In Famose J. P. (2002).Apprentissage moteur et motivation, Congrès international de la SFPS, Paris : INSEP, $29 \mathrm{pp}$.

[10] Famose, J.P. (1991). Apprentissage moteur et résolution des problèmes. In Famose, J.P., Fleurance, P.H \& Touchard, Y. Apprentissage moteur, rôle des représentations, Paris : Revue EPS, pp 97-118. 
[11] Henry, M. (1991). La notion de contrat didactique, In Douady, R. (1994). Cahiers de didactique des Mathématiques, $\mathrm{n}^{\circ} 6$ : pp16, IREM de Besançon.

[12] Lahanier-Reuter, D. (2008). Performances et apprentissages en didactique des mathématiques. Les Cahiers Théodule, 9 : 45-60.

[13] Le Boterf, G. (1997). De la compétence à la navigation professionnelle. In Le Boterf, G. (1999). Compétence et navigation professionnelle, Paris : Organisation, 324pp.

[14] Loquetm, G. \&Amade-Escot, C. (2002). Transmission des savoirs en activités physiques et sportives et artistiques dans des institutions différentes : enseignement scolaire, entraînement sportif, transmissionchorégraphique. Revue Française de Pédagogie, 141 : 99-109.

[15] Mourgues, B. (2000). Contribution à une approche socio-didactique des comportements d'élèves : L'exemple de l'EPS. Mémoire de DEA, Université de Reims.

[16] Robert, R. S. \& James, R. F. (1969). Biometry: the Principe and practices of statistics in Biological research, 267p.

[17] Routier, G. (2011). De l'engagement au désengagement corporel : Une approche sociologique plurielle des dynamiques, ruptures et permanences identitaires face à l'acceptation du danger dans les sports de nature. Thèse de Doctorat de l'Université Haute Bretagne de Rennes 2, Tome 1.

[18] Schmidth, R. A. (1999). Apprentissage moteur et performance. Paris, Vigot, 362pp.

[19] Sensevy, G. (2006). Agir ensemble. L'action conjointe professeur-élèves dans le système didactique, P..U..Rennes.

[20] Suchman, L. (1987). Plans and situated actions, Cambridge: Cambridge University.

[21] Thepaut, A. \& Leziart, Y. (2013). Performance et apprentissage disciplinaire en Education Physique et Sportive : Une étude des performances didactiques en jeux sportifs collectifs à l'école élémentaire, e JRIEPS.

[22] Thibault, H., Duche, P., Meyer, M. \& Peres, G. (2010). Activité physique et obésité de l'enfant : Base pour une prescription adaptée. Ministère de la Santé, de la Jeunesse, des Sports et de la vie associative de la République Française, Paris : Editions INSEP.

[23] Touboul, A. (2011). Les effets de l'expérience et de l'expertise dans les pratiques enseignantes en EPS. Etude clinique en Savate boxe française. Thèse de Doctorat de l'Université de TOULOUSE II- Le Mirail. 